\title{
The Effect of Age and Workload on Work Posture toward Musculoskeletal Disorders Complain on Loading and Unloading Workers
}

\author{
Syamsiar S. Russeng ${ }^{1 *}$ (D) Lalu Muhammad Saleh ${ }^{1}$ D, Widya Nur Wahyulianti ${ }^{1}$, Sukri Palutturi ${ }^{2}$ (D) \\ ${ }^{1}$ Department of Occupational Health and Safety, Faculty of Public Health, Universitas Hasanuddin, Makassar, Indonesia; \\ ${ }^{2}$ Department of Health Administration and Policy, Faculty of Public Health, Universitas Hasanuddin, Makassar, Indonesia
}

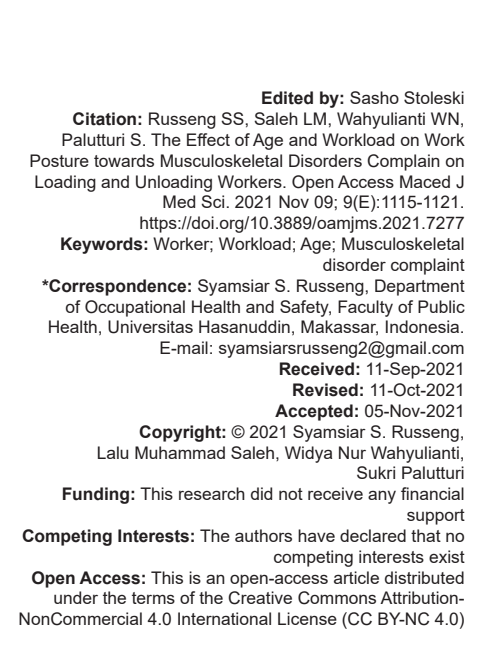

\section{Introduction}

One of the global issues encountered by workers and the workplace is to create a healthy workplace setting [1], [2]. The working process using manual material handling such as loading, unloading, pulling, throwing, moving, or rotating the load using the hands or other body parts causes the workers to develop musculoskeletal disorders (MSDs) risk. Loading and unloading workers are at risk of experiencing health problems or occupational diseases, such as MSDs. Factors causing complaints in the musculoskeletal system include excessive muscle stretching, repetitive activities, and unnatural work postures. This complaint usually occurs in the spine (back and neck) and upper limbs. The results of studies in several industries revealed that the muscles of the neck, shoulders, arms, hands, fingers, back, waist, and lower muscles are the muscle parts that often complained by the sufferer [3]. Therefore, one of the health problems for loading and unloading workers is low back pain (LBP). It is estimated that around $80 \%$ of the world's population has experienced at least one LBP during their lifetime. It was reported that $28-41 \%$ of workers who suffered from back pain complaints have never been treated until they recovered. Furthermore, approximately, $60-80 \%$ of people in the UK have also suffered from LBP. Therefore, this disease becomes one of the main reason's workers are absent from work, thus millions of working days are lost every year. The proportion of back pain incidence, especially lower back pain, has become endemic in the UK and the United States. Based on the survey that was carried out it the UK, it was discovered that 17.3 million people UK have suffered from back pain. Moreover, 1.1 million people among them experienced paralysis due to back pain [4]. The most prevalent WMSDs were located at the back (overall), shoulder/neck, neck, shoulder, lower back, and wrist WMSDs with mean 12-month prevalence values of $60,54,51,50,47$, and $42 \%$, respectively, and WMSDs are still highly present among blue collar workers. Relatively high prevalence values and low incidence ratios indicate a limited onset of WMSDs with however long-term complaints [5]. 
Riskfactors ofMSDsareclassified into individual factors, occupational factors, and environmental factors. Individual factors include age, gender, body mass index (BMI), years of service, physical activity, income level, smoking habits, and education. Occupational factors include workload, work posture, duration, and repetition. Meanwhile, environmental factors include vibration and noise [6]. It is reported that $79-89 \%$ of the populations of developed countries have experienced; LBP complaints which is also a disease that is most frequently consulted by doctors. This disease often occurs at the age of 35-55-years-old. Most acute back pain is self-limiting and only $2-7 \%$ become chronic [7].

Workload is an activity consisting of physical and mental loads that must be completed within a certain time. In this case, physical workload requires muscle physical energy as the energy source. The activity of carrying heavy loads manually causes a high physical workload. Musculoskeletal system complaints commonly caused by excessive muscle contraction due to excessive workload and long duration of loading. Such complain can also be experienced by transport workers, in which the load weight being loaded causes damage to the intervertebral disc layer (the element that lies between the vertebrae) due to the emphasis on the spinal segment (L5/S1). Damage to the intervertebral disc layer causes pressure and irritates the nerve roots, causing pain. Another damage caused by the load weight being loaded continuously is damage to the muscles, ligaments, and tendons in the area which worsen the pain complaints [8], [9].

The WHO states that $2-5 \%$ of the industrialized countries' population suffered from LBP annually. National Safety Council reported that the highest occupational disease frequency case occurs is LBP, which is $22 \%$ of $1,700,000$ cases [10]. The number of LBP sufferers in Indonesia is unknown, but it is estimated between $7.6 \%$ and $37 \%$ of the population. Research from the pain study group of the Indonesian Neurologist Association (PERDOSSI) discovered that the number of LBP sufferers was $35.86 \%$ of the total pain patients' visits [11]. Furthermore, it is also estimated that around $40 \%$ of the Central Java Province population aged over 65-years-old have suffered from LBP, of which $18.2 \%$ of them are men and $13.6 \%$ of them are women. Based on data on occupational diseases (PAK), there were 57,929 cases in $2011,60,322$ cases in 2012, 97,144 cases in 2013, and 40,694 cases in 2014. In 2011, the highest cases occurred in Central Java Province with 1,120 cases [12]. It was reported that the cases prevalence in Indonesia was (18\%), which increases as the age also increases. In this case, most of them occurred on soft tissue, which is mostly caused by muscle injury, ligament injury, muscle spasm, or fatigue [13].

Most of the respondents in this study were aged 35 years and over and had a heavy workload, and the work was done repeatedly so they were at risk for experiencing very large MSDs complaints. The study was proposed to analyze the effect of age and workload on MSDs through work posture as the intervening variable on loading and unloading workers at PT. Port of Indonesia IV (Persero) of Makassar Branch in 2021.

\section{Methods}

The current research was conducted through an analytical observation using a cross-sectional approach. The research population is workers at PT. Port of Indonesia IV (Persero) of Makassar Branch in 2021 that is 216 people and the sample formula use the slovin formula so that the total sample size is 140 respondents, then the sampling technique is simple random sampling. The sample inclusion criteria are workers who work at PT Intan Sejahtera Utama. PT Intan Sejahtera Utama is a company engaged in providing labor services with Indonesian legal entities. On this basis, PT Pelindo 4 entered into a partnership with PT Intan Sejahtera Utama as a provider of labor services. The exclusion criteria were: (1) had a fall that caused hip trauma, (2) had and temporarily suffered from kidney disease, (3) had and temporarily suffered from a spinal disorder, (4) had and temporarily suffered from a neurological disease.

Data collection is the respondent's characteristics, namely age, work experience which is measured by using a questionnaire. Then, the measurement of BMI is carried out by measuring the weight and height of the respondent. MSDs measurement using Nordic Body Map (NBM), LBP complaints using Oswestry Disability Index (ODI), and workload measurement by measuring pulse using a pulse oximeter. Furthermore, work posture was evaluated using Rapid Entire Body Assessment (REBA). The REBA method is a method in the field of ergonomics that is used to quickly assess the posture of the neck, back, arms, wrists, and legs of workers. This method is used to measure the work attitude of workers. The evaluator/appraiser will judge from each body part that is assessed based on the REBA form [14].

The validity test process is carried out by measuring the correlation between the statement items and the total items. Criteria Indicators in the questionnaire can be said to be valid if the $p$-value of the result is smaller than the value of $=0.05$.

Based on the Table 1, it is found that all statement items used to measure variable $F$ (MSDs NBM) and variable G (LBP ODI) have $p<0.05$ meaning that all statement items are able to measure variable F (MSDs NBM) and variable G (LBP ODI) well. Based on the Table 2, the value of Cronbach's alpha $>0.60$ standard of reliability so that it can be said that the two variables are reliable. 
Table 1: Test the validity of research instruments

\begin{tabular}{|c|c|c|c|c|}
\hline Variable & Statement & $p$-value & $\alpha$ & Information \\
\hline \multirow[t]{28}{*}{ F (MSDs NBM) } & F0 & 0.000 & \multirow[t]{28}{*}{0.05} & Valid \\
\hline & F1 & 0.000 & & Valid \\
\hline & F2 & 0.000 & & Valid \\
\hline & F3 & 0.000 & & Valid \\
\hline & F4 & 0.000 & & Valid \\
\hline & F5 & 0.000 & & Valid \\
\hline & F6 & 0.000 & & Valid \\
\hline & F7 & 0.000 & & Valid \\
\hline & F8 & 0.000 & & Valid \\
\hline & F9 & 0.000 & & Valid \\
\hline & F10 & 0.000 & & Valid \\
\hline & F11 & 0.000 & & Valid \\
\hline & F12 & 0.000 & & Valid \\
\hline & F13 & 0.000 & & Valid \\
\hline & F14 & 0.000 & & Valid \\
\hline & F15 & 0.000 & & Valid \\
\hline & F16 & 0.000 & & Valid \\
\hline & F17 & 0.000 & & Valid \\
\hline & F18 & 0.000 & & Valid \\
\hline & F19 & 0.000 & & Valid \\
\hline & F20 & 0.000 & & Valid \\
\hline & F21 & 0.000 & & Valid \\
\hline & F22 & 0.000 & & Valid \\
\hline & F23 & 0.000 & & Valid \\
\hline & F24 & 0.000 & & Valid \\
\hline & F25 & 0.000 & & Valid \\
\hline & F26 & 0.000 & & Valid \\
\hline & F27 & 0.000 & & Valid \\
\hline \multirow[t]{5}{*}{ G (LBP ODI) } & G1 & 0.000 & \multirow[t]{5}{*}{0.05} & Valid \\
\hline & G2 & 0.000 & & Valid \\
\hline & G3 & 0.000 & & Valid \\
\hline & G4 & 0.000 & & Valid \\
\hline & G5 & 0.000 & & Valid \\
\hline
\end{tabular}

index.

Category of each variable: (1) Age [7]: Young ( $<35$-years-old) and Old ( $\geq 35$-years-old); (2)Years of service: New ( $<5$ years) and Old ( $\geq 5$ years); (3) BMI [15]: Normal Range, Overweight at Risk, Overweight Obese 1 , Overweight Obese 2; (4)Workload [16]: Acceptable Level, Moderate Level, High Level, Intolerable Level; (5) MSDs Complaint [17]: Low, Moderate, High, Very high; (6) Work Posture[18]: Ergonomic, Non-Ergonomic; (7) LBP Complaint [19]: Minimal disability, Moderate disability, Severe disability, very severe disability, Unable to conduct activity.

\section{Table 2: Reliability test results}

\begin{tabular}{llll}
\hline Variable & Cronbach's Alpha & Reliability standard & Information \\
\hline F (MSDs NBM) & 0.962 & 0.60 & Reliable \\
G (LBP ODI) & 0.857 & 0.60 & Reliable \\
\hline MSDs: Musculoskeletal disorders, NBM: Nordic body map, LBP: Low back pain, ODI: Oswestry disability
\end{tabular}
index.

Data analysis is by univariate, bivariate using Chi-square with $p<0.05$, and multivariate analysis using the SPSS program.

\section{Results}

Table 3 shows that among 140 respondents involved in the current research, most of the respondents were categorized in the old age group by 101 respondents $(62.1 \%), 87$ respondents $(62.1 \%)$ were categorized to the long service category, 61 respondents' BMI was categorized in the normal range $(43.6 \%), 73$ respondents' workload was at the moderate level $(52.1 \%)$, and 65 respondents $(46.4 \%)$
Table 3: Respondents' characteristics $(n=140)$

\begin{tabular}{|c|c|c|}
\hline Respondents' characteristics & $\mathrm{n}$ & $\%$ \\
\hline \multicolumn{3}{|l|}{ Age } \\
\hline Young (<35-years-old) & 39 & 27.9 \\
\hline Old ( $\geq 35$-years-old) & 101 & 72.1 \\
\hline \multicolumn{3}{|l|}{ Years of service } \\
\hline New $(<5$ years $)$ & 53 & 37.9 \\
\hline Old ( $\geq 5$ years) & 87 & 62.1 \\
\hline \multicolumn{3}{|l|}{ BMI } \\
\hline Normal range & 61 & 43.6 \\
\hline Overweight at risk & 34 & 24.3 \\
\hline Overweight obese 1 & 41 & 29.3 \\
\hline Overweight obese 2 & 4 & 2.9 \\
\hline \multicolumn{3}{|l|}{ Workload } \\
\hline Acceptabel level & 14 & 10 \\
\hline Moderate level & 73 & 52.1 \\
\hline High level & 50 & 35.7 \\
\hline Intolerable level & 3 & 2.1 \\
\hline \multicolumn{3}{|l|}{ MSDs complaint } \\
\hline Low & 18 & 12.9 \\
\hline Moderate & 4 & 2.9 \\
\hline High & 65 & 46.4 \\
\hline Very high & 53 & 37.9 \\
\hline \multicolumn{3}{|l|}{ Work posture } \\
\hline Ergonomic & 15 & 10.7 \\
\hline Non-ergonomic & 125 & 89.3 \\
\hline \multicolumn{3}{|l|}{ LPB complaint } \\
\hline Minimal disability & 19 & 13.6 \\
\hline Moderate disability & 89 & 63.6 \\
\hline Severe disability & 29 & 20.7 \\
\hline Very severe disability & 3 & 2.1 \\
\hline Unable to conduct activity & 0 & 0 \\
\hline
\end{tabular}

suffered from MSDs at a high category followed by a very high musculoskeletal disorder complaint in 53 respondents $(37.9 \%)$. Furthermore, based on the LBP complaint evaluated using ODI, there are 89 respondents $(63.6 \%)$ who suffered moderate disability and those who had non-ergonomic work postures were 125 respondents $(89.3 \%)$.

Furthermore, multivariate analysis was carried out to analyze the relationship between endogenous variables and exogenous variables, which is the path analysis test. Path analysis consists of direct and indirect effects. In this case, regression analysis was used to obtain the direct and indirect effect values. The following results were obtained in Figure 1.

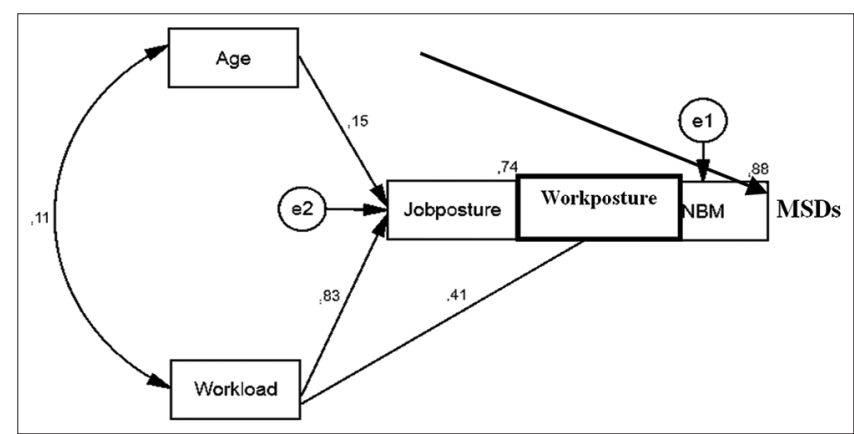

Figure 1: Path analysis of the effect of age and workload through work posture on musculoskeletal disorders complaints

The Figure 1 related to the effects of age and workload through work posture on MSDs complaints on loading and unloading workers at PT. Pelabuhan Indonesia of Makassar Branch, and then the path analysis obtained the following results.

Based on the Table 4, the results of the direct influence above can be explained as follows: 
Table 4: The direct effect of endogenous and exogenous variable on loading and unloading workers at PT. Pelabuhan Indonesia IV (Persero) of Makassar Branch

\begin{tabular}{lll}
\hline Direct effect & Path coefficient & p-value \\
\hline Workload on work posture & 0.834 & 0.000 \\
Age on work posture & 0.147 & 0.000 \\
Workload on MSDs & 0.408 & 0.000 \\
Work posture on MSDs & 0,569 & 0.000 \\
Age on MSDs & 0.74 & 0.167 \\
Age on workload & 0.11 & 0.105 \\
\hline Source: Primary Data, 2021. MSDs: Musculoskeletal disorders. &
\end{tabular}

The workload variable effect on work posture has a p-value of $0.000<0.05$, indicating that the workload variable has a significant positive effect on the work posture variable with a path coefficient value $\left(X_{1} \rightarrow M\right)$ of 0.834

The age variable effect on the work posture has a p-value of $0.000<0.05$, indicating that the age variable has a significant positive effect on the work posture variable with the path coefficient value $\left(X_{2} \rightarrow M\right)$ of 0.147

The workload variable effect on MSDs has a p-value of $0.000<0.05$, indicating that the workload variable has a significant positive effect on the musculoskeletal disorder's variable with the path coefficient value $\left(X_{1} \rightarrow Y\right)$ of 0.408 .

The work posture variable effect on musculoskeletal disorder has a p-value of $0.000<0.05$, indicating that the work posture variable has a significant positive effect on the musculoskeletal disorder's variable with a path coefficient value $(\mathrm{M} \rightarrow \mathrm{Y})$ of 0.569

Furthermore, the results of the indirect effect based on path analysis are explained as follows:

The indirect effect of age variable on MSDs through work posture variable was obtained by multiplying the coefficient of the age path on work posture and work posture on MSDs $\left(X_{1} \rightarrow M \rightarrow Y\right)=(0.147 \times 0.569)=0.084$

The indirect effect of workload variable on MSDs variable through work posture variable was obtained by multiplying the workload path coefficient on work posture and work posture on $\operatorname{MSDs}\left(X_{2} \rightarrow M \rightarrow Y\right)=(0.834 \times 0.569)=0.475$.

Furthermore, to know the significance of the direct effect of workload variable on musculoskeletal disorder complaints through work postures, Sobel test was carried out and obtaining the following results:

It is known:

$a=0.115$ (regression coefficient of workload on work posture)

$b=5.297$ (regression coefficient of work posture on MSDs complaint)

$\mathrm{S}_{\mathrm{a}}=0.006$ (standard error value of workload on work posture)
$S_{b}=0.510$ (standard error value of work posture on MSDs complaint)

$$
\begin{aligned}
& z-\text { value }=\frac{a b}{\sqrt{b^{2} S^{2}{ }_{a}+a^{2} S^{2}{ }_{b}}} \\
& z-\text { value }=\frac{(0.115)(5.297)}{(5.297)^{2}(0.006)^{2}+(0.115)^{2}(0.510)^{2}}
\end{aligned}
$$

z-value $=9.13170363$ (the significance of the direct effect of workload variable on MSD complaints through work postures).

Furthermore, to know the significance of indirect effect of age variable on MSDs variable through work posture, Sobel test was also carried out, obtaining the following results:

It is known that:

$a=0.115$ (regression coefficient of age on work posture)

$b=5.297$ (regression coefficient of work posture on MSDs)

$S_{a}=0.006$ (standard error value of age on work posture)

$S_{b}=0.510$ (standard error value of work posture on MSDs)

$$
z-\text { value }=\frac{a b}{\sqrt{b^{2} S^{2}{ }_{a}+a^{2} S^{2}{ }_{b}}}
$$

$$
z-\text { value }=\frac{(0.039)(5.297)}{(5.297)^{2}(0.011)^{2}+(0.039)^{2}(0.510)^{2}}
$$

z-value $=3.3553469$ (the significance of indirect effect of age variable on MSDs variable through work posture).

The following is the calculation results presented in Table 5

Table 5: Results of indirect effect

\begin{tabular}{lll}
\hline Indirect effect & z-value & Description \\
\hline Work load on MSDs through work posture & 9.13170363 & $\begin{array}{l}z \text {-value>z-absolute 1.96 } \\
\text { (significant and indirect effect) }\end{array}$ \\
Age on MSDs through work posture & 3.3553469 & $\begin{array}{l}\text { z-value }>\text {-absolute 1.96 } \\
\text { (significant and indirect effect) }\end{array}$ \\
\hline MSDs: Musculoskeletal disorders. & &
\end{tabular}

Based on the Table 5, the z-value of workload on MSDs through the work posture is 9.13170363 which is more than the z-absolute of 1.96 . Therefore, it can be summed up that the workload variable has significant and indirect effect on the musculoskeletal disorder's variable through the work posture variable. Furthermore, the test results of the age on MSDs complaints through work postures obtained value 
of 3.3553469 which is more than the z-absolute of 1.96. Therefore, it can also be summed up that age has a significant and indirect effect on MSDs complaints through work postures.

\section{Discussion}

\section{Workload on MSDs complain}

The data on workload level of loading and unloading workers at PT. Pelabuhan Indonesia IV (Persero) of Makassar Branch reported that the workers who had moderate level workload (medium load) is more than those who had a heavy workload (Table 3). The workers' workload is in the form of loading, transporting, carrying, and others. Heavy and repeated loads will cause health problems in the form of MSDs complaints. This can be seen from the NBM assessment that 82 workers $(58.6 \%)$ suffered from waist pain and 90 respondents $(64.3 \%)$ suffered from back (buttocks) pain. In addition, loading heavy loads with non-ergonomic work postures will put pressure on the intervertebral discs so that it can trigger hernia nucleus pulposus which will cause pain in the spine at the waist as well as in the lower back (LBP). In this case, there were 89 respondents $(63.6 \%)$ who suffered from LBP complaints at the moderate disability category.

Furthermore, the workload was measured by calculating the cardiovascular load. The results of statistical test values indicated that the workload affects MSDs in loading and unloading workers at PT. Pelabuhan Indonesia IV (Persero) of Makassar Branch with a p-value of $p=0.000<0.05$. This study is in line with the previous research that was conducted by Puspitasari and Rindu (2017) on 55 midwives, obtaining that there was a direct influence between physical activity by $4.18 \%$, traumatic by $18.74 \%$, workload by $36.6 \%$, and work stress by $15.1 \%$. Thus, it can be seen that the effect of workload on MSDs complaints is higher than the other variables [20]. Another research was also conducted by Nurzannah et al. (2015) finding that there is a significant effect on the proportion of loading and unloading workers (TKBM) who suffered from LBP in TKBM between those who had moderate workload and those who had light workload. The difference can be seen from the OR value obtained of $0.304(0.108 \pm 0.861)$, indicating that those who moderate level of workload had 0.304 times more risk of suffering from LBP in TKBM than those who had a light workload [21]. Physical workload has significant association with MSDs complaints among worker or in other word increasing of physical workload would be increase complain of MSDs [22]. Physical tasks related to spatial planning, work conditions, workload conditions, lifting and transportation methods and others affect one's fatigue, the accumulation of this physical workload can cause muscles to contract more and result in musculoskeletal complaints [3].

\section{Age on MSDs complaint}

Concerning the age of the loading and unloading workers at PT. Pelabuhan Indonesia IV (Persero) of Makassar Branch, 101 respondents (72.1\%) were categorized at the old age category ( $>35$ years). Based on the path analysis test that has been conducted, it showed that $\mathrm{np}$ direct and significant effect was found between the age and musculoskeletal disorder complaints with a p-value of 0.167 (>0.05). However, there was an indirectly significant effect on musculoskeletal disorder complaints through work posture. In addition, most of the respondents were at risk age (>35 years) who suffered from MSDs. They also work with risky or non-ergonomic work postures, indicated by 125 respondents who worked with non-ergonomic work postures caused by decreased bone elasticity and improper work posture. Furthermore, the respondents who were at the non-risk age ( $\leq 35$ years) can also suffer from MSDs complaints although the proportion is small. This result is supported by the previous research that was conducted by Mulyati, (2018), who found a relationship between work posture and MSDs in laundry worker [23]. Similar results also occurred on the weavers. This generally occurs due to risky work postures such as an abnormal spine during weaving [24].

In addition, another previous research project was also conducted by Bilondatu, 2018 [25] stating that among 70 workers, $82.4 \%$ of 36 young people suffered from LBP and $44.4 \%$ of 34 old people also suffered from LBP. The results of this study indicate that there is a significant relationship between age and the incidence of LBP in loading workers in the logistics warehouse of the regional sub-division of Bulog Makassar [25]. A person's age is directly proportional to his physical capacity to some extent and reaches its peak at the age of 25 years. At the age of $50-60$ years, muscle strength decreases by $25 \%$ and at above 60 -years-old a person's physical work capability reaches $50 \%$ only of the age of a 25-years-old person [26]. As a person's age increases, bone density decreases so that it is easy to experience skeletal muscle complaints and cause pain. Maximum muscle strength occurs between the age of 20-29 years, and it will decrease by $20 \%$ at the age of 60-years-old in addition to other factors due to non-ergonomic attitudes resulting in LBP [27]. Other research shows that there were moderate correlations between the age and the MSDs complaints (phi coefficient $=0.335$ ), between the years of service and the MSDs complaints (phi coefficient $=0.433$ ), and between the working postures and MSDs complaints (phi coefficient $=0.401)[28]$. 


\section{Age on MSDs through work posture}

Based on the statistical test that has been conducted on the indirect effect of age on MSDs through work posture, the value obtained was $(X-M-Z)=(0.147 \times 0.5697)=0.084$. Meanwhile, according to the Sobel test, the indirect effect of age on MSDs through work postures, obtained z-value of $=3.3553469$ which is more than the $z$-absolute of 1.96. Therefore, it can be summed up that age variable has significant and indirect effect on MSDs through work postures. Previous research implemented by Sari (2017) revealed that there is a relationship between age and MSDs complaints with $p=0.005<0.05$. Such a relationship occurs because as the workers are getting older, their muscle strength has begun to decrease as well so that the risk of MSDs complaints increases [29].

In addition, research by Muliati (2018) conducted a statistical test results, obtaining a p-value of 0.002 ( $p<0.005)$, meaning that work posture significantly affects MSDs in laundry workers at the Sukamerindu Health Center. The results obtained are $\mathrm{OR}=11.818$, which means that workers who work with non-ergonomic work postures have 12 times more chance of suffering from MSDs compared to workers who work with ergonomic work postures. This can be seen that 125 respondents (89.3\%) work with non-ergonomic work postures. Other research shows that for younger workers, physical hazards were not associated with MSD risk. In contrast, for those aged $36-49$, repetitive movements $(B=1.76, p<0.001)$ and awkward postures $(B=1.30, p=0.02)$ were associated with increased MSD risk. For older workers, environmental hazards were positively associated with MSD risk ( $B=0.37, p=0.04)$. Predictors of MSD risk changed differently for each age group during 4 years of follow-up. For younger workers, change in environment and repetitive movements, for middle age team support and for older workers change in awkward posture were significant predictors of MSD risk [30].

\section{Workload on MSDs through work posture}

Another statistical test was also conducted on the indirect effect of workload on MSDs through work postures, obtaining $(\mathrm{X} 2-\mathrm{M}-\mathrm{Z})=(0.834 \times 0.569)$ $=0.47538$. Furthermore, the Sobel test obtained that the indirect effect of workload on MSDs through work posture, obtained z-value of 9.13170363 which is more than the z-absolute of 1.96. Therefore, it can be summed up that workload has a significant and indirect effect on MSDs through work posture variable. Therefore, it can be assumed that MSDs in workers occurred due to the workload and non-ergonomic work postures. MSDs are also occurred due to repetitive activities that can affect the workers' workload [31]. Other research shows that the heavier the physical workload, the higher the MSDs complaints among nurses [32]. On the other hand, ergonomic problems emerge due to adverse postural stresses, heavy loads, repetitive movements, vibrations, and temperature changes [33]. The works with static working postures are more familiar with the MSDs complaints around the lower back, neck, and back [34].

\section{Conclusion}

A significant indirect effect was also found between age and MSDs through work posture. In addition, most of the workers suffered from LBP complaints at moderate disability. There is a significant indirect effect between workload on MSDs through work posture variables. In this case, it is recommended that loading and unloading workers should work in accordance with their abilities and paying attention to ergonomic work postures, including by not bending over when lifting weights, taking steps before lifting loads and not exceeding the weight of the load recommended.

\section{References}

1. Palutturi S. Healthy Cities Implementation in Indonesia: Challenges and Determinants of Successful Partnership Development at Local Government Level, Griffith Thesis. Australia: Griffith University; 2013. https://doi. org/10.25904/1912/52

2. Palutturi S, Thaha RM, Fitry IN. The effect of the implementation of makassar healthy city based on capacity building and sustainability. Open Access Maced J Med Sci. 2020;8(2):215-9. https://doi.org/10.3889/oamjms.2020.5236

3. Tarwaka P. Dasar Dasar Pengetahuan Ergonomi dan Aplikasi di Tempat Kerja. Singapore: Solo, Harapan Press; 2015.

4. Septiawan H. Faktor berhubungan keluhan nyeri punggung bawah pada pekerja bangunan pt mikroland Semarang. Unnes J Public Health. 2013;1(2):2. https://doi.org/10.15294/ujph. v2i2.2992

5. Govaerts R, Tassignon B, Ghillebert J, Serrien B, De Bock S, Ampe T, et al. Prevalence and incidence of workrelated musculoskeletal disorders in secondary industries of $21^{\text {st }}$ century Europe: A systematic review and meta-analysis. BMC Musculoskeletal Disorders. 2021;22(1):751. https://doi. org/10.1186/s12891-021-04615-9.

6. Kuppusamy S, Narayanasamy R, Christopher J. Effectiveness of mckenzie exercises and mat based pilates exercises in subjects with chronic non-specific low back pain: A comparative study. Int J Prev Treat. 2013;2(4):47-54.

7. Andini F. Risk factors of low back pain in workers. J Majority. 2015;4(1):1.

8. Nugroho IA, Marchianti AC, Hermansyah Y. Influence of workload level on low back pain patient's physical disabilities at RSD dr. Soebandi jember. Pustaka Kesehatan. 2017;5(2):316-22. 
9. Nurmianto E, Ergonomi, Konsep Dasar dan Aplikasinya. Surabaya: Prima Printing; 2005. Available from: http://www. repo.unikadelasalle.ac.id\%2Findex.php\%3Fp\%3Dshow detail\%26id\%3D4040\%26keywords\%3D. [Last accessed on 2021 Sep 12].

10. Siti R, Zulfia M. Factors affecting low back pain complaint to workers in gravity casting area automotive industry Indonesia. E3S Web Conf. 2018;73:06013. https://doi.org/10.1051/ e3sconf/20187306013

11. Aditianti A, Raswanti I, Sudikno S, Izwardy D, Irianto SE. Prevalence and stunting risk factors in children 24-59 months in Indonesia: Analysis of basic health research data 2018. J Nutr Food Res. 2020;43(2):2. https://doi.org/10.22435/pgm. v43i2.3862

12. Purnamasari H, Gunarso U, Rujito L. Overweight sebagai faktor resiko low back pain pada pasien poli saraf RSUD Prof. Dr. Margono soekarjo purwokerto. Mandala Health. 2010;4(1):26-32.

13. Ikhtiani FC. Analysis Work Posture and Education to Prevent the Risk of Low Back Pain of Students Prosthetics and Orthotics Department Polytechnic of Health Sciences Jakarta I Ministry of Health of Republic of Indonesia, Thesis. Jakarta: Politeknik Kesehatan Kementerian Kesehatan Jakarta; 2019. Available from: http://www.r2kn.litbang.kemkes.go.id:8080/ handle/123456789/78649. [Last accessed on 2021 Sep 12].

14. Hignett S, McAtamney L. Rapid entire body assessment (REBA). Appl Ergon. 2000;31(2):201-5. https://doi.org/10.1016/ s0003-6870(99)00039-3

PMid:10711982

15. Weir $\mathrm{CB}$, Jan A. BMI classification percentile and cut off points. In: StatPearls. Treasure Island, FL: StatPearls Publishing; 2021. Available from: http://www.ncbi.nlm.nih.gov/books/NBK541070. [Last accessed on 2021 Oct 12].

16. Suryoputro MR, Ginanjar TC, Sari AD. Combining time and physical workload analysis on cold press working group for operator management in manufacturing company. MATEC Web Conf. 2018;221:02007. https://doi.org/10.1051/ matecconf/201822102007

17. Prabarukmi GS, Widajati N. The correlation of ergonomic risk factor with musculoskeletal complaints in Batik workers. Indones J Occup Saf Health. 2020;9(3):269-78.

18. Pramestari D. Analisis postur tubuh pekerja menggunakan metode ovako work posture analysis system (owas). J Sains Teknol. 2017;1(2):2.

19. Hayashi Y. Classification, diagnosis, and treatment of low back pain. JMAJ. 2004;47(5):227-33.

20. Puspitasari D, Rindu R. Pengukuran faktor yang berpengaruh terhadap keluhan nyeri punggung bawah pada Bidan. J IImiah Kesehatan. 2017;16(2):2. https://doi.org/10.33221/jikes. v16i02.287

21. Nurzannah N, Sinaga M, Salmah U. Hubungan faktor resiko dengan terjadinya nyeri punggung bawah (low back pain) pada tenaga kerja bongkar muat (Tkbm) di pelabuhan belawan medan tahun 2015. Lingkungan Keselamatan Kerja. 2015;4(1):1-10.

22. Putri PS. Hubungan beban kerja fisik dengan keluhan musculoskeletal disorders pada pekerja di pabrik sepatu di Nganjuk. J Keperawatan Muhammadiyah. 2019;4(1):1. https:// doi.org/10.30651/jkm.v4i1.2044

23. Mulyati S. The Relationship Between Work Posture And Musculoskeletal Disorders (Msds). Indonesia: In Laundry Workers in the Area of Puskesmas Sukamerindu Bengkulu; 2019. p. 171-4. https://doi.org/10.2991/icihc-18.2019.41

24. Ones M, Sahdan M, Tira DS. Faktor yang Berhubungan dengan Keluhan Nyeri punggung bawah (low back pain) pada penenun di desa letneo selatan kecamatan insana barat kabupaten timor tengah Utara. Med Kesehatan Masyarakat. 2021;3(1):1. https:// doi.org/10.35508/mkm.v3i1.2958

25. Bilondatu F. Faktor Yang Berhubungan Dengan Kejadian Low Back Pain Pada Operator PT. Terminal Petikemas Makassar Tahun 2018, Thesis. Makassar: Universitas Hasanuddin; 2018.

26. Tarwaka T, Solichul HA, Bakri B, Sudiajeng L. Ergonomi Untuk Keselamatan, Kesehatan Kerja Dan Produktivitas. Surakarta: UNIBA; 2004.

27. Pheasant S, Haslegrave CM. Bodyspace: Anthropometry, Ergonomics, and the Design of Work. $3^{\text {rd }}$ ed. Boca Raton: Taylor \& Francis; 2006

28. Putri BA. The correlation between age, years of service, and working postures and the complaints of musculoskeletal disorders. IJOSH. 2019;8(2):187-96. https://doi.org/10.20473/ ijosh.v8i2.2019.187-196

29. Sari EN, Handayani L, Saufi A. Hubungan antara umur dan masa kerja dengan keluhan musculoskeletal disorders (MSDs) pada Pekerja Laundry. J Kedokteran Kesehatan. 2017;13(2):2. https://doi.org/10.24853/jkk.13.2.183-194

30. Oakman J, Neupane $\mathrm{S}$, Nygård $\mathrm{CH}$. Does age matter in predicting musculoskeletal disorder risk? An analysis of workplace predictors over 4 years. Int Arch Occup Environ Health. 2016;89(7):1127-36. https://doi.org/10.1007/ s00420-016-1149-z PMid:27368425

31. Fallentin N, Viikari-Juntura E, Waersted M, Kilbom A. Evaluation of physical workload standards and guidelines from a Nordic perspective. Scand J Work Environ Health. 2001;27(2):1-52. PMid:11775634

32. Aeni HF, Banowati L, Nur'alinda T. Correlation between physical workload and musculoskeletal disorders complaints among nurses at hospital. Indones J Occup Saf Health. 2020;9(1):1. https://doi.org/10.20473/ijosh.v9i1.2020.88-94

33. Özkaya K, Polat O, Kalinkara V. Physical workload assessment of furniture industry workers by using owas method. Ergonom Open J. 2018;11(1):11-9. https://doi. org/10.2174/1875934301811010011

34. Daika N. Correlation between working postures and the complaints of musculoskeletal diseases of the fishermen in Tanjung village, Sumenep district. Indones J Occup Saf Health. 2019;8(3):3. https://doi.org/10.20473/ijosh.v8i3.2019.258-264 